\title{
Rhizoctonia web blight of soybean in Pakistan
}

\author{
M. Siddique Mirza and Yasmin Ahmed
}

National Agricultural Research Centre, Islamabad, Pakistan

(received 12 April 1989, accepted 04 October 1989)

\begin{abstract}
Summary - Rhizoctonia aerial or web blight of soybean (Glycine max (L.) Merril) caused by Rhizoctonia solani Kuehn was observed for the first time under high humidity and temperatures at the National Agricultural Research Centre, Islamabad in 1983 and again in 1985 and 1987. Pathogenicity tests and reisolation from the inoculated plants confirmed that Rhizoctonia solani was the cause of soybean web blight.
\end{abstract}

Rhizoctonia solani - Glycine max - web blight - temperature - moisture

Résumé - Attaques du soja par Rhizoctonia solani Kuehn au Pakistan. Des attaques de Rhizoctonia solani Kuehn sur soja (Glycine max (L.) Merril) ont été observées pour la première fois au Centre National de Recherches Agricoles d'lslamabad en 1983 dans des conditions d'humidité et de température élevées. D'autres attaques ont ensuite été observées en 1985 et 1987. Des tests et l'isolation à partir d'individus inoculés ont confirmé qu'il s'agissait bien de Rhizoctonia solani.

Rhizoctonia solani - Glycine max - rhizoctone brun - température - humidité

\section{INTRODUCTION}

Web blight of soybean (Glycine max (L.) Merril.) caused by Rhizoctonia solani Kuehn has been reported in subtropical and tropical regions of the world. It was first reported in the Phillippines (Reinking, 1918; Nacian, 1924) and has since been reported from Brazil (Machado et al. 1973), Colombia (Patino, 1967), Egypt (El-Helaly et al., 1972), Germany (Noll, 1939), India (Verma \& Thapliyal, 1974), Malaya (Voelcker, 1953), Mexico (Crispin \& Gallegos, 1963), Puerto Rico (Hepperly et al., 1982), China (Chein \& Chung, 1963), Taiwan and Louisiana (Atkins \& Lewis, 1954). In Louisiana, yield losses of $35 \%$ have been attributed to web blight (Horn \& Fontenot, 1980). In India incidence of web blight reached $80-90 \%$ in unsprayed plots, while in benomyl sprayed plots, the disease was controlled and yield increased significantly (Verma \& Thapliyal, 1974). Atkins \& Lewis (1954) have reported on the host range of the pathogen.

Although Rhizoctonia web blight may have been present earlier, it was first observed in soybean experimental plots at the National Agricultural Research Centre, Islamabad (NARC), during September 1983 and then in 1985-1987 under high humidity and warm temperatures.

The purpose of this paper is to report the occurrence, identification and the pathogenicity of the Rhizoctonia solani on soybean from Pakistan.

\section{MATERIALS AND METHODS}

Disease symptoms of Rhizoctonia web blight were first observed at pod filling stage and infected plants of the soybean variety Davis were collected from an experimental plot at NARC, Islamabad. For isolation, 3-4 $\mathrm{mm}$ segments of infected leaves were surface sterilized in $0.1 \%$ sodium hypochlorite solution for $1 \mathrm{~min}$, rinsed in sterile water and plated on $9 \mathrm{~cm}$ Petriplates containing $15 \mathrm{~mL}$ of potato dextrose agar (PDA) and then incubated at $25^{\circ} \mathrm{C}$ for 7 days. Observations on cultural characteristics and growth of the fungus were recorded daily.

For determining the pathogenicity a 5-7 day old Petri dish culture of $R$. solani on PDA was comminuted 
in $300 \mathrm{~mL}$ of distilled water for $5 \mathrm{~min}$ in a Waring Blender to prepare an inoculum suspension. Following this 4-5-week old aerial plant parts of the variety "Davis" were artificially inoculated by spraying them with mycelial suspension. Inoculated plants were kept in a moist chamber for $24 \mathrm{~h}$ and then transferred to a greenhouse at $30{ }^{\circ} \mathrm{C}$ with $95 \%$ relative humidity and a $12 \mathrm{~h}$ photoperiod.

\section{RESULTS AND DISCUSSION}

\section{Natural symptoms}

Disease symptoms which developed on the leaves were greenish to reddish brown necrotic areas of circular-irregular shape with reddish brown margins. The affected plants showed 30$80 \%$ defoliation. In severe infection, the whole leaflets were blighted and a grey to tan coloured mycelium growth with microsclerotia was observed in the necrotic areas under high humidity and warm temperatures. In addition, lesions formed on the petioles and stem of severely infected plants. Typical sclerotia of irregular shape, dark brown coloured and ranging from $200-260 \times 295-480 \mu \mathrm{m}$ in size were also observed on the leaf lesions.

\section{Isolation and identification}

Characteristic mycelium branching at right angles with constrictions at the base of hyphal branches covered the entire PDA plate at $25{ }^{\circ} \mathrm{C}$ after $48 \mathrm{~h}$. Sclerotia on PDA were $3-5 \mathrm{~mm}$ in diameter, and cinnamon-coloured. Based on the cultural characteristics of mycelium and sclerotia, the pathogen was identified as Rhizoctonia solani Kuehn.

\section{Pathogenicity}

On the artificially inoculated plants, symptoms first appeared as water soaked circular to irregular spots on the leaves which later turned brown to $\tan$ coloured or reddish brown. Our Rhizoctonia isolate produced disease symptoms identical to those observed in the naturally infected plants within 7-10 days in the greenhouse. The pathogen was consistently reisolated from the artificially infected plants, confirming its pathogenicity.
The pathogen has a different host range and apart from soybean, it can attack common bean (Phaseolus vulgaris), lima bean ( $P$. limensis), clover (Trifolium spp.), cowpeas (Vigna spp.) fescue (Festuca spp.), fig (Ficus spp.), lespedezas (Lespedeza spp.), rice (Oryza sativa), wild soybeans (Glycine javanica) and tung (Aleurites spp.) as reported by Sinclair (1982). Although, the disease has also been reported on mungbean ( $V$. radiata) by Alam et al. (1985); however, this appears to be the first report of web blight ( $R$. solani) on soybean from Pakistan.

\section{REFERENCES}

Alam S.S., Qureshi S.H. \& Bashir A. (1985) A report on web blight of mungbean in Pakistan. Pak. J. Bot. 17,165

Atkins J.G. \& Lewis W.D. (1954) Rhizoctonia aerial blight of soybean in Louisiana. Phytopathology 44, 215-218

Chein C.C. \& Chung S.C. (1963) Physiologic races of Pellicularia sasaki (syn. Thanatephorus cucumeris, Rhizoctonia solani) in Taiwan. Taiwan Agric. Res. 12, 1-6

Crispin A. \& Gallegos C.C. (1963) Web blight: a severe disease of beans and soybeans in Mexico. Plant Dis. Rep. 47, 1 010-1 011

El-Helaly A.F., Ibrahim I.A., Michail S.H. \& Abdel Aziz F.R. (1972) Studies on the damping off and root rot of soybean in Egypt. Phytopathol. Mediterr. 11, 202-204

Hepperly P.R., Sinclair J.B., Smith R.S. \& Judy W.H. (1982) Rhizoctonia web blight of soybean in Puerto Rico. Plant Dis. 66, 256-257

Horn N.L. \& Fontenot M.F. (1980) Control of aerial blight with foliar spray, 1979. Fungicide Nematicide Tests 35, 111

Machado C.C., Gomes J.C. \& Lehman P.S. (1973) Dead patch of soybeans in southern Brazil. 2nd Int. Cong. Plant Pathol., abstr. 1062

Nacian C.C. (1924) Study of Rhizoctonia blight of beans. Philipp. Agric. 12, 315-321

Noll W. (1939) Studies on foot rot and wilt diseases in Leguminosae in German. Z. Pflanzenkr. 49, 385-431

Patino H.C. (1967) Diseases of oleaginous annuals in Columbia. Agric. Trop. 23, 532-539

Reinking O.A. (1918) Philippine economic plant diseases. Philipp. J. Sci. 13, 165-274

Sinclair J.B. (1982) Compendium of Soybean Diseases. Am. Phytopathol. Soc., St. Paul, USA, 2nd edn, $23 \mathrm{p}$

Verma H.S. \& Thapliyal P.N. (1974) Soybean (Glycine max) Rhizoctonia aerial blight (Rhizoctonia solani). Fungicide Nematicide Tests, 1973 results. 29, 95

Voelcker O.J. (1953) 1952 Annual Report Dept. Agric. Malaya, $65 \mathrm{p}$ 